\title{
Cholesterol embolism: it's always a good idea to look into the eye
}

\author{
Alfredo lardino, ${ }^{1}$ Orlando Garner, ${ }^{1}$ Ana Ramirez, ${ }^{1}$ Franco Lotta ${ }^{2}$
}

'Department of Internal Medicine, Texas Tech University at the Permian Basin, Odessa, Texas, USA

2Department of Critical Care Medicine, Centro Policlinico Valencia "La Viña", Valencia, Venezuela

\section{Correspondence to}

Dr Alfredo lardino,

alfredo.iardino@ttuhsc.edu

Accepted 3 September 2017
To cite: lardino A, Garner 0 , Ramirez A, et al. BMJ Case Rep Published Online First: [please include Day Month Year]. doi:10.1136/bcr-2017 222128

\section{DESCRIPTION}

Atheroembolism is a rare but feared complication of arteriography, causing a myriad of signs and symptoms including livedo reticularis, abdominal pain, cyanosis of the toes and renal injury. The main cause is a rupture of atherosclerotic plaque in vessel walls and its embolisation to small diameter vessels affecting more frequently skin and kidneys. ${ }^{1}$ Here, we present a 69-year-old Hispanic male with medical history of hypertension, type 2 diabetes mellitus and unstable angina status post drug-eluting stent in the left anterior descending coronary artery placement 10 days prior to admission, who arrived to the emergency department with intense diffuse sharp abdominal pain, nausea, vomiting, oliguria and lower extremity pain. Physical examination disclosed livedo reticularis in lower extremities (figure 1), tender abdomen with decreased bowel sounds and funduscopy positive for a Hollenhorst crystal observed in right inferotemporal quadrant (figure 2) and increased creatinine and blood urea nitrogen. Patient was treated with methylprednisolone $125 \mathrm{mg}$ three times a day which improved patient's abdominal symptoms, renal function and skin findings. He was discharged 16 days later with prednisone $50 \mathrm{mg}$ po and was followed up over a

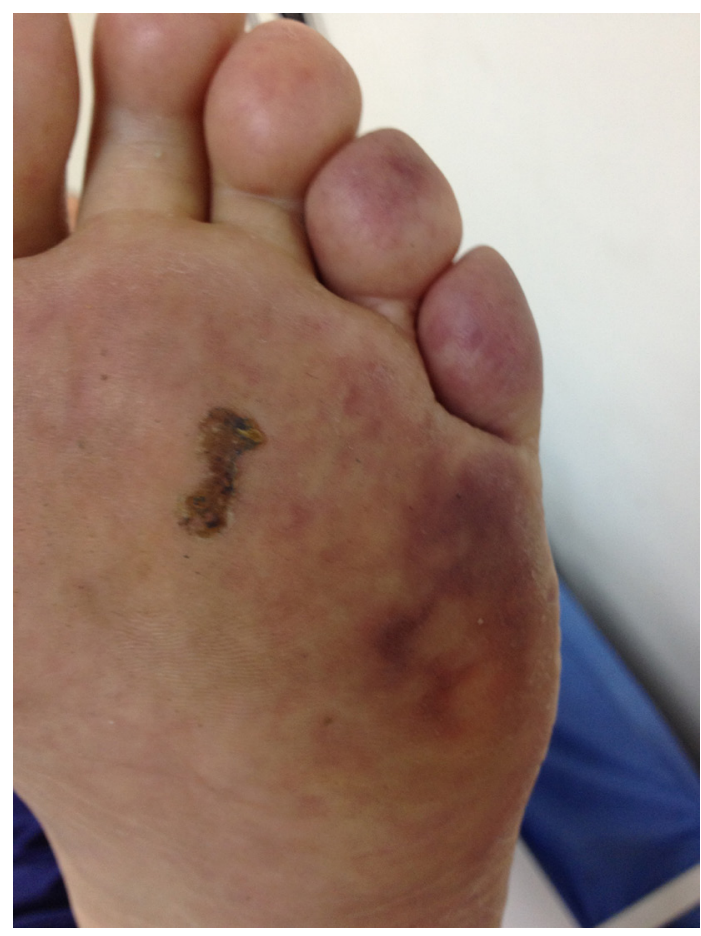

Figure 1 Left foot sole with findings consistent with livedo reticularis and blue toe sign.

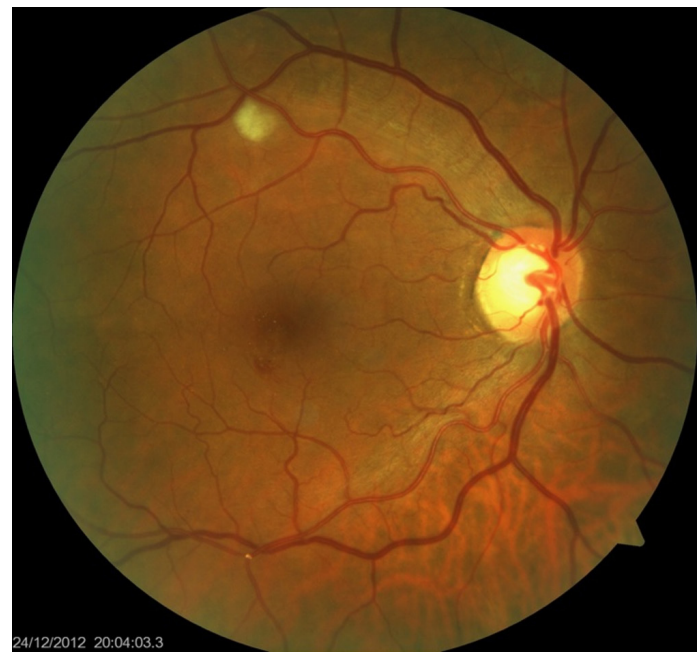

Figure 2 Funduscopy picture where a Hollenhorst crystal can be observed in right inferotemporal quadrant.

year with resolution of initial symptoms. Management of atheroembolism is usually supportive and depends on the affected organ; to our knowledge, there are no formal studies that have evaluated treating this complication with anti-inflammatory therapies. $^{2} 3$ Physical exam is fundamental when approaching patient like this, funduscopy was an essential part of the examination and spared the patient from undergoing invasive diagnostic studies like biopsies, as well as opportune initiation of treatment.

\section{Learning points}

Funduscopy is an important part of the physical exam and needs to be done in all patients examined.

- When examining a patient, we need to take into account multiple differential diagnoses; in this specific case, contrast-induced renal failure could be the cause of the majority of the patient's symptoms, but after using a combination of physical exam findings and differential diagnosis, adequate treatment was started.

- There are diseases that do not always have a set treatment; bibliographic review needs to be made in these cases in order to offer our patient the best change to improve.

Contributors Al was responsible for the patient care, editing of the figures, writing of the manuscript and bibliographic search. OG was responsible for the manuscript editing and details and bibliographic search. AR was repsonsible for the bibliographic 
search. FL was the senior advisor responsible for patient care, fundoscopy technique and treatment.

Competing interests None declared.

Patient consent Obtained.

Provenance and peer review Not commissioned; externally peer reviewed.

(c) BMJ Publishing Group Ltd (unless otherwise stated in the text of the article) 2017. All rights reserved. No commercial use is permitted unless otherwise expressly granted.

\section{REFERENCES}

1 Tunick PA, Kronzon I. Atheromas of the thoracic aorta: clinical and therapeutic update. $J$ Am Coll Cardiol 2000;35:545-54

2 Mann SJ, Sos TA. Treatment of atheroembolization with corticosteroids. Am J Hypertens 2001:14:831-4.

3 Motegi S, Abe M, Shimizu A, et al. Cholesterol crystal embolization: skin manifestation, gastrointestinal and central nervous symptom treated with corticosteroid. J Dermatol 2005:32:295-8

Copyright 2017 BMJ Publishing Group. All rights reserved. For permission to reuse any of this content visit

http://group.bmj.com/group/rights-licensing/permissions.

BMJ Case Report Fellows may re-use this article for personal use and teaching without any further permission.

Become a Fellow of BMJ Case Reports today and you can:

- Submit as many cases as you like

- Enjoy fast sympathetic peer review and rapid publication of accepted articles

- Access all the published articles

Re-use any of the published material for personal use and teaching without further permission

For information on Institutional Fellowships contact consortiasales@bmjgroup.com

Visit casereports.bmj.com for more articles like this and to become a Fellow 